\title{
IMPLEMENTASI STANDAR OPERASIONAL PROSEDUR (SOP) PELAYANAN AKTA KELAHIRAN PADA DINAS KEPENDUDUKAN DAN PENCATATAN SIPIL KOTA BENGKULU
}

\author{
Ida Anggriani \\ Meiffa Herfianti \\ Dosen Fakultas Ekonomi Universitas Dehasen Bengkulu \\ meiffaherfianti@gmail.com
}

\begin{abstract}
ABSTRAK
Meiffa Herfianti; Tujuan dari penelitian ini adalah untuk mengetahui implementasi SOP pelayanan akta kelahiran pada Dinas Kependudukan dan Pencatatan Sipil di Kota Bengkulu. Metode analisis data yang digunakan adalah analisis deskriptif dan analisis kualitatif. Hasil penelitian menunjukkan bahwa: (1) Pada tahap persiapan pelaksanaan SOP pelayanan penerbitan akta kelahiran di Dinas Dukcapil Kota Bengkulu telah dilaksanakan dengan baik. Sosialisasi SOP telah dilakukan dengan baik, sarana dan prasarana pelayanan telah disusun dengan baik, tugas dan tanggung jawab petugas telah dibagi dengan tepat, sehingga memperlancar proses pelayanan kepada masyarakat. Sosialisasi dilakukan melalui rapat staf tiap tiga bulan sekali yang bertujuan untuk mengevaluasi kinerja layanan akta catatan sipil termasuk didalamnya pelayanan akta kelahiran. Dari kegiatan rapat evaluasi tersebut diidentifikasi faktor penghambat layanan dan dibahas bersama untuk mencari solusinya. Sosialisasi SOP kepada masyarakat dilakukan dengan cara menempel Alur Pelayanan (SOP) Pada papan pengumunan di Kantor Dinas Kependudukan dan Pencatatan Sipil, agar masyarakat yang datang dapat melihat langsung alur pelayanan yang diselenggarakan oleh Dinas Dukcapil Kota Bengkulu dan (2) Implementasi SOP pelaksanaan penerbitan akta kelahiran di Dinas Dukcapil Kota Bengkulu dari tahap menerima dan memeriksa berkas permohonan akta kelahiran, verifikasi berkas permohonan, mengagendakan dan mengumpulkan berkas permohonan, menginput data dan mencetak akta kelahiran, memeriksa, memaraf dan menandatangani, dan menyerahkan kutipan akta kelahiran kepada masyarakat telah dilaksanakan dengan sesuai dengan tahapan pelayanan yang ditetapkan. Setiap pegawai yang terlibat dalam pelayanan akta kelahiran telah bekerja sesuai dengan tanggung jawabnya masing-masing.
\end{abstract}

\begin{abstract}
Meiffa Herfianti; The purpose of this research is to know the implementation of SOP (Standard Operational Procedures) for birth certificate services at the Population and Civil Registration Board of Bengkulu City. The method of the data analysis was used is descriptive and qualitative analysis. The study shows that: (1) the preparation phase of the implementation of SOP services at the Population and Civil Registration Board has been executed well, where socialization SOP has been done properly, the SOP has been well implemented and equipment of the Ministry has been drafted and personals, has been shared with the right personnel, so as to facilitate the process of service to the community and (2) the implementation of SOP implementation the issuance of a birth certificate in the Population and Civil Registration Board of Bengkulu City from the stage of receiving and examining the file the petition for a birth certificate, file verification application scheduled, and collect files petition, enter data and print a birth certificate, check, legacy and sign, and submit the quote birth certificate to the community have been implemented in accordance with the stages of service assigned. Every employee involved in the birth certificate service has been implemented in accordance with the stages of service assigned.
\end{abstract}

Keywords: Policy implementation, Standard Operational Procedure; and Birth Certificate

\section{PENDAHULUAN}

Sistem birokrasi di era otonomi ini sangat diharapkan dapat berperan secara optimal dalam menjalankan fungsi-fungsinya. Keberadaan oknum aparatur pemerintah (birokrat) tertentu di dalam pemerintahan seringkali dipandang dikotomis dan menimbulkan anggapan masyarakat luas bahwa seluruh sistem pemerintahan dan pelayanan publik tersendat dan bertele-tele. Berbagai kritik tentang inefesiensi dalam sistem birokrasi, kualitasnya yang terlalu besar dan kaku sudah sering dinyatakan secara terbuka. Sistem pencaloan yang merajalela, nepotisme serta terjadinya berbagai patologi birokrasi menyiratkan bahwa reformasi birokrasi harus dilakukan. Reformasi birokrasi tidak sekedar 
menyederhanakan struktur birokrasi, tapi juga mengubah pola pikir (mind set) aparatur pemerintahan didalamnya untuk berbagi peran dalam tata kelola pemerintahan (Fatah, 2000:33).

Salah satu tujuan diterapkannya kebijakan otonomi daerah adalah untuk meningkatkan kualitas pelayanan publik dari pemerintah daerah kepada warga masyarakatnya. Pelayanan publik adalah pelayanan yang wajib diselenggarakan negara untuk pemenuhan kebutuhan dasar atau hak-hak dasar warga negara (publik) (Ibrahim, 2008:45). Ketiadaan atau kurang memadainya pelayanan publik akan mengakibatkan tidak terpenuhinya hak asasi manusia oleh penyelenggara negara. Pelayanan publik harus diberikan pada setiap warga negara, baik yang kaya maupun miskin, baik yang berada di pusat kemajuan maupun daerah terbelakang, baik yang mendatangkan keuntungan atau membutuhkan subsidi. Karena itu negara harus mengambil peranan dan tanggung jawab dalam penyelenggaraan pelayanan publik.

Pelayanan publik (public services) oleh birokrasi publik dimaksudkan untuk mensejahterakan masyarakat selaku komponen warga negara dari suatu negara berorientasi pada suatu kesejahteraan (welfare state). Hal ini sesuai dengan Undang-Undang Nomor 12 Tahun 2008 yang kemudian diubah dengan Undang-Undang Nomor 23 Tahun 2014 tentang Pemerintah Daerah, yang menyebutkan bahwa pemerintah kabupaten/kota mempunyai kewenangan terbatas dalam lingkup otonomi daerah, dalam memaksimalkan pelayanan yang berbasis kesejahteraan masyarakat.

Pemerintah memiliki peran penting sebagai salah satu faktor strategis untuk mewujudkan kesejahteraan masyarakat. Sekalipun tingkat sosial dan ekonomi suatu masyarakat telah meningkat, peran pemerintah tetap diperlukan. Pemerintah berkewajiban untuk mengarahkan, membimbing, dan menciptakan suasana yang menunjang kegiatan masyarakat.Sektor pelayanan kepada masyarakat adalah prioritas dalam menterjemahkan undang-undang otonomi daerah. Benang merah dari pola kebijakan yang seragam dalam mensiasati birokrasi pelayanan sangatlah berarti bagi kemajuan program pemerintah itu sendiri. Salah satu sektor pelayanan publik di tingkat daerah adalah pelayanan akta kelahiran.

Menurut Peraturan Menteri Negera Pendayagunaan Aparatur Negara Nomor 12 Tahun 2008, SOP (Standard Operating Prosedure) adalah serangkaian instruksi tertulis yang dibakukan (terdokumentasi) mengenai berbagai proses penyelenggaraan administrasi pemerintahan, bagaimana dan kapan harus dilakukan, dimana dan oleh siapa dilakukan. Standar Operasional Prosedur (SOP) pada dasarnya adalah pedoman yang berisi prosedur-prosedur operasional standar yang ada dalam suatu organisasi yang digunakan untuk memastikan bahwa semua keputusan dan tindakan, serta penggunaan fasilitas-fasilitas proses yang dilakukan oleh orang-orang dalam organisasi berjalan secara efisien dan efektif, konsisten, standar dan sistematis.

Berdasarkan Undang-Undang Nomor 23 Tahun 2006 tentang Administrasi Kependudukan yang telah diubah dengan Undang-Undang Nomor 24 tahun 2013 tentang perubahan atas Undang-Undang Nomor 23 Tahun 2006 tentang Administrasi Kependudukan, telah dikualifikasikan bahwa jenis pelayanan akta kelahiran meliputi pelayanan pencatatan akta kelahiran, pelayanan pencatatan akta perkawinan, pelayanan pencatatan akta perceraian, pelayanan pencatatan akta kematian, dan pelayanan pencatatan akta pengangkatan anak.

Proses pelayanan akta kelahiran di Kota Bengkulu tidak luput dari permasalahan. Permasalahan yang menggangu proses pelayanan yakni karena tidak konsistennya regulasi yang dijalankan oleh Pemerintah Kota Bengkulu. Pada Peraturan Daerah Kota Bengkulu No.7 Tahun 2011 tentang Retribusi Penggantian Biaya Cetak Kartu Tanda Penduduk dan Akta Pencatatan Sipil dikenakan retribusi biaya penggantian cetak. Artinya, setiap warga masyarakat Kota Bengkulu yang mengurus akta pencatatan sipil seperti akta kelahiran dan KTP dikenakan biaya penggantian cetak akta. Sementara, pada tahun yang sama juga Peraturan Bupati Lebong Nomor 16 Tahun 2011 yang menyatakan bahwa biaya pembuatan akta harus gratis. Peraturan Bupati tersebut sebagai penjabaran dari dan Undang-Undang No.23/2006 yang mengamanatkan bahwa pembuatan akta harus gratis.

Menyikapi kesimpang-siuran aturan yang ada di Kota Bengkulu tersebut, Dinas Kependudukan dan Pencatatan Sipil sebagai instansi yang melaksanakan tugas dan kewenangan mengeluarkan akta kelahiran menjadi kebingungan, sehingga saat ini untuk pelaksanaan penerbitan akta kelahiran, pegawai Dinas Dukcapil Kota Bengkulu melakukan pemungutan 'uang sukarela', artinya, jika ada masyarakat yang memberikan sejumlah uang tertentu tetap diambil, tetapi jika masyarakat tidak memberikan juga tidak dipermasalahkan.

Permasalahan berikutnya adalah belum dilaksanakannya SOP (standard operating procedure)pelayanan akta kelahiran dengan baik, sehingga pelayanan dirasakan masih sangat lama, berbelit-belit, dan tidak efisien jika tidak disertai dengan 'uang sukarela' tersebut. Namun, jika masyarakat memberikan 'uang sukarela' maka proses penerbitan akta kelahiran dilakukan dengan cepat sesuai dengan 'pesanan' oknum masyarakat yang memberikan uang sukarela tersebut.

Sebagai suatu instrumen manajemen, SOP yang berlandaskan pada sistem manajemen kualitas (Quality Management System), yakni sekumpulan prosedur terdokumentasi dan praktek-praktek standar 
untuk manajemen sistem yang bertujuan menjamin kesesuaian dari suatu proses dan produk (barang dan/atau jasa) terhadap kebutuhan atau persyaratan tertentu. Sistem manajemen kualitas berfokus pada konsistensi dari proses kerja. Hal ini mencakup beberapa tingkat dokumentasi terhadap standar-standar kerja. Sistem ini berlandaskan pada pencegahan kesalahan, sehingga bersifat proaktif, bukan pada deteksi kesalahan yang bersifat reaktif.

Melalui pelaksanaan dan penerapan SOP yang benar, diharapkan dapat meningkatkan efisiensi dan efektifitas kinerja layanan yang diberikan, karena dengan adanya instruksi kerja yang terstandarisasi maka semua kegiatan layanan akan dapat dilakukan secara konsisten oleh siapapun yang sedang bertugas melakukan layanan. Layanan-layanan yang berbelit dan tidak jelas prosedur operasinya akan semakin terminimalisir, terlebih lagi untuk menghindari praktik-praktik illegal yang merugikan masyarakat dan kas daerah.

\section{LANDASAN TEORI Kebijakan Publik}

Makna modern dari gagasan "kebijakan" dalam bahasa Inggris adalah seperangkat aksi atau rencana yang mengandung tujuan politik (Wilson dalam Parson, 2008:14). Sejak periode pasca Perang Dunia II. Kata 'policy'mengandung makna kebijakan sebagai sebuah rationale, sebuah manifestasi dari penilaian penuh pertimbangan. Sebuah kebijakan adalah usaha untuk mendefenisikan dan menyusun basis rasional untuk melakukan atau tidak melakukan suatu tindakan (Parson, 2008: 14).

Kata "publik" secara terminologi mengandung arti sekelompok orang atau masyarakat dengan kepentingan tertentu. Menurut Parson (2008: 3) publik adalah aktivitas manusia yang dipandang perlu untuk diatur atau diintervensi oleh pemerintah atau aturan sosial, atau setidaknya oleh tindakan bersama. Hal ini berarti bahwa masyarakat atau publik datang dengan latar belakang kepentingan yang diwujudkan dalam bentuk tuntutan (demand) dan dukungan (support). Intervensi terhadap publik oleh pemerintah ataupun oleh aturan sosialnya mendorong terjadinya perubahan-perubahan terhadap publik melalui usaha-usaha yang telah direncanakan. Terlepas dari perubahan tersebut membawa dampak yang bersifat baik maupun dampak yang bersifat buruk.

Usaha pemerintah untuk merespon kepentingan publik ini adalah yang disebut dengan kebijakan publik. Dye (1995:66) mendefenisikan kebijakan publik sebagai apa yang dilakukan pemerintah, mengapa dilakukan dan apa yang membuatnya berbeda. Laswell dan Kaplan (dalam Marijan, 2010:6) mendefenisikan kebijakan publik sebagai usaha mencapai tujuan, nilaidan pelaksanaannya. Easton (dalam Nugroho, 2006:23) mendefenisikan kebijakan publik sebagai dampak dari upaya pemerintah.Menurut Obsorne (dalam Marijan, 2010: 6), dalam menghadapi tuntutan-tuntutan yang berkembang di dalam masyarakat, sistem politik dapat menempuhnya melalui dua cara. Pertama, membuat keputusankeputusan sebagaimana yang diinginkan oleh masyarakat. Kedua, melakukan politisasi, yaitu membangun nilai-nilai yang ada di dalam pemerintahan.

Berdasarkan defenisi dari para pakar tersebut dapat disimpulkan bahwa kebijakan publik adalah segala sesuatu yang dikerjakan dan yang tidak dikerjakan oleh pemerintah. "Dikerjakan" atau "tidak dikerjakan" merupakan keputusan, karena dilakukan atau tidak dilakukan tetap akan memberikan dampak.

\section{Standar Operasional Prosedur (SOP)}

Peraturan Menteri Pendayagunaan Aparatur Negara menyatakan, SOP (standard operating prosedure) adalah serangkaian instruksi tertulis yang dibakukan (terdokumentasi) mengenai berbagai proses penyelenggaraan administrasi perusahaan, bagaimana dan kapan harus dilakukan, dimana dan oleh siapa dilakukan. SOP adalah serangkaian instruksi yang menggambarkan pendokumentasian dari kegiatan yang dilakukan secara berulang pada sebuah organisasi berdasarkan (Permendagri, 2008).

Lebiht lanjut Permenpan dan RB (2012) menjelaskan bahwa Standar Operasional Prosedur (SOP) pada dasarnya adalah pedoman yang berisi prosedur-prosedur operasional standar yang ada dalam suatu organisasi yang digunakan untuk memastikan bahwa semua keputusan dan tindakan, serta penggunaan fasilitas-fasilitas proses yang dilakukan oleh orang-orang dalam organisasi berjalan secara efisien dan efektif, konsisten, standar dan sistematis. Dengan adanya sistem manual standar atau SOP diharapkan dapat meningkatkan efisiensi dan efektifitas kinerja layanan yang diberikan. Dengan adanya instruksi kerja yang terstandarisasi maka semua kegiatan layanan akan dapat dilakukan secara konsisten oleh siapapun yang sedang bertugas melakukan layanan. Layanan-layanan yang berbelit dan tidak jelas prosedur operasinya akan semakin terminimalisir.

Di samping konsistensi layanan hal lain yang akan dihasilkan adalah efisiensi dan efektifitas kerja. Dengan prosedur yang terstandar setiap orang baik pengguna layanan maupun staf yang memberi layanan akan dapat memanfaatkan ataupun melakukan layanan yang semakin hari semakin baik dan semakin cepat 
karena terjadinya proses pembelajaran yang secara terus menerus terjadi selama proses layanan. Dengan demikin dapat dipastikan melalui SOP ini akan dapat meningkatkan efisiensi dan efektifitas kerja layanan (Gie, 2000:44).

Dilihat dari fungsinya, SOP berfungsi membentuk sistem kerja dan aliran kerja yang teratur, sistematis, dan dapat dipertanggung jawabkan. SOP menggambarkan bagaimana tujuan pekerjaan dilaksanakan sesuai dengan kebijakan dan peraturan yang berlaku. SOP juga menjelaskan bagaimana proses pelaksanaan kegiatan berlangsung, sebagai sarana tata urutan dari pelaksanaan dan pengadministrasian pekerjaan harian sebagaimana metode yang ditetapkan, menjamin konsistensi dan proses kerja yang sistematik, dan menetapkan hubungan timbal balik antar Satuan Kerja.

Sebagai sistem yang bertitik tolak pada kualitas maka SOP berlaku pada seluruh aspek pekerjaan manusia yang salah satunya adalah administrasi perkantoran (office administration/ office management) Administrasi perkantoran merupakan urusan yang tidak dapat dilepaskan dari penyelenggaraan urusan publik maupun privat baik yang diselenggarakan oleh pemerintah, swasta maupun perseorangan.

Dalam hal ini pengertian administrasi perkantoran yang dimaksud yaitu: rangkaian aktivitas POAC yaitu merencanakan, mengorganisasi (mengatur dan menyusun), mengarahkan (memberikan arah dan petunjuk), mengawasi, dan mengendalikan (melakukan kontrol) sampai menyelenggarakan secara tertib sesuatu hal menyangkut pekerjaan perkantoran (office work)-dalam arti sempit maupun dalam arti luas (Gie, 2000:47).

Selanjutnya dalam rangka peningkatan pelayanan dan kinerja organisasi pada umumnya dan peningkatan pelayanan dan kinerjapenyelenggaraan urusan administrasi perkantoran pada khususnya maka administrasi perkantoran memerlukan adanya suatu pedoman pelaksanaan yang memberikan arah dan rambu-rambu yang dipergunakan dalam pencapaian tujuan yang telah ditentukan secara efektif dengan didukung oleh peraturan yang berlaku.

Khusus pada organisasi pemerintah pedoman pelaksanaan administrasi perkantoran yang dapat meningkatkan pelayanan dan kinerja organisasi merujuk pada Peraturan Menteri Pendayagunaan Aparatur Negara Nomor Nomor 35 tahun 2012 tentang Pedoman Penyusunan Standar Operasional Prosedur Administrasi Pemerintahan (SOP-AP) yang merupakan tindak lanjut dari Peraturan Menteri Pendayagunaan Aparatur Negara Nomor PER/15/M.PAN/7/2008 tentang Pedoman Umum Reformasi Birokrasi. Peraturan ini mengamanatkan perlunya penyusunan Standar Operasional Prosedur Administrasi Pemerintahan (SOP-AP) sebagai pelaksanaan Reformasi Birokrasi di seluruh Kementerian/Lembaga/Pemerintah Daerah yang bertujuan secara umum untuk membangun/membentuk perilaku aparatur negara dengan integritas tinggi, produktivitas tinggi dan bertanggung jawab serta kemampuan memberikan pelayanan yang prima melalui pembaharuan dan perubahan mendasar terhadap sistem penyelenggaraan pemerintahan terutama menyangkut aspek kelembagaan (organisasi), ketatalaksanaan (business process) dan aspek sumber daya aparatur. Atau dapat dikatakan bahwa Penyusunan SOP merupakan salah satu unsur penting dalam pelaksanaan penyelenggaraan pemerintahan dalam peningkatan pelayanan dan kinerja organisasi.

SOP Sebagai Pedoman Pelaksanaan Administrasi Perkantoran dan Peningkatan Pelayanan. Konsep Standar Operasional Prosedur merupakan istilah organisasi dan manajemen yang merujuk pada sistem pengawasan manajemen (management control system). Dalam pengertian ini maka SOP diartikan sebagai peraturan dan regulasi yang merupakan kebijakan untuk menjamin kebenaran (validitas) perilaku anggota organisasi secara terus menerus. Daft (1992 : 89), menyatakan bahwa SOP merupakan bagian dari 4 (empat) subsistem pengawasan manajemen dan fokus dari pengawasan (four management control) Subsystems and Focus of Control yang diilustrasikan sebagai berikut 


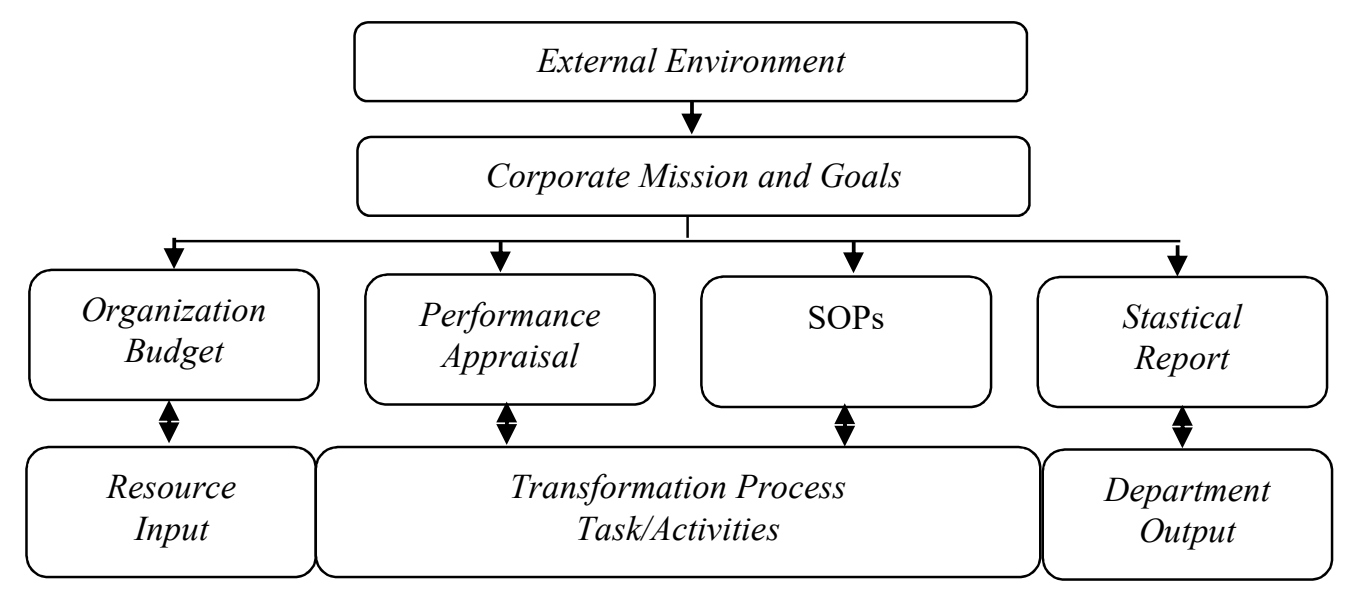

Gambar 1. Four Management Control Subsystems and Focus of Control

Berdasarkan konsep ini maka SOP memberikan secara eksplisit pedoman mengenai aktivitas yang diperlukan meskipun pengawasan secara langsung dari supervisi yang menghubungkan penilaian kinerja dengan prosedur yang menjamin aktivitas pekerjaan (bagian) yang sangat terbatas.

Selanjutnya Jones (dalam Purwanto, 2012:19) menyatakan:

...Written rules and standard operating procedures and unwritten values and norms help to control behavior in organization. The specify how an employee is to perform his or her organization role, and they set forth the tasks and responsibilities associated with that role.

Berdasarkan pendapat ini maka dapat dipahami bahwa SOP merupakan bagian dari peraturan tertulis yang membantu untuk mengontrol perilaku anggota organisasi. SOP mengatur cara pekerja untuk melakukan peran keorganisasiannya secara terus menerus dalam pelaksanaan tugas dan tanggung jawab organisasi.

Secara umum, SOP pada hakekatnya berarti suatu cara untuk menghindari miskomunikasi, konflik, dan permasalahan pada pelaksanaan tugas/pekerjaan pada suatu organisasi. Hal ini dapat dimungkinkan karena SOP merupakan petunjuk tertulis yang menggambarkan dengan tepat cara melaksanakan tugas/pekerjaan. Tidak hanya itu, SOP juga berisi mekanisme untuk mengkomunikasikan peraturandan persyaratan administratif, kebijakan organisatoris dan perencanaan strategis bagi pegawai/pekerja. Atau dengan kata lain bahwa dengan adanya SOP maka semua orang membaca irama musik yang sama.

\section{Pelayanan}

Pelayanan berasal dari kata pelayan yang berarti perihal atau cara melayani, sedangkan menurut istilah pelayanan adalah aktivitas yang diberikan untuk membantu, menyiapkan dan mengurus baik itu berupa barang atau jasa dari suatu pihak kepada pihak lain. Menurut Shadely (1996:223) pelayanan memiliki tiga makna, (1) perihal atau cara melayani; (2) usaha melayani kebutuhan orang lain dengan memperoleh imbalan (uang); (3) kemudahan yang diberikan sehubungan dengan jual beli barang atau jasa (Hardiyansyah, 2011).

Menurut Keputusan Menpan Nomor 63 Tahun 2003 tentang Pelayanan Publik, yang dimaksud pelayanan adalah segala kegiatan pelayanan yang dilaksanakan oleh penyelenggara pelayanan publik sebagai upaya pemenuhan kebutuhan penerima pelayanan maupun pelaksanaan ketentuan peraturan perundang-undangan." Sejalan dengan Rancangan Undang Undang Pelayanan Publik Republik Indonesia (RUU Pelayanan Publik, 2007:2) memaknai pelayanan publik adalah kegiatan atau rangkaian kegiatan dalam rangka pemenuhan kebutuhan dasar sesuai dengan hak-hak sipil setiap warga negara dan penduduk atas suatu barang, jasa, dan atau pelayanan administrasi yang disediakan oleh penyelenggara pelayanan publik.

Ada tiga fungsi pelayanan umum (publik) yang dilakukan pemerintah yaitu environmental service, development service dan protective service. Pelayanan oleh pemerintah juga dibedakan berdasarkan siapa yang menikmati atau menerima dampak layanan baik individu maupun kelompok. Konsep barang layanan pada dasarnya terdiri dari barang layanan privat (private goods) dan barang layanan kolektif (public goods). 
Pelayanan umum oleh lembaga Administrasi Negara diartikan sebagai segala bentuk kegiatan pelayanan umum yang dilaksanakan oleh instansi pemerintah di Pusat, di Daerah dan di lingkungan Badan Usaha Milik Negara/Daerah dalam bentuk barang dan atau jasa baik dalam rangka upaya kebutuhan masyarakat maupun dalam rangka pelaksanaan ketentuan peraturan perundang-undangan. Pelayanan publik dengan demikian dapat diartikan sebagai pemberian layanan (melayani) keperluan orang atau masyarakat yang mempunyai kepentingan pada organisasi itu sesuai dengan aturan pokok dan tata cara yang telah ditetapkan. Sementara itu, kondisi masyarakat saat ini telah terjadi suatu perkembagan yang sangat dinamis, tingkat kehidupan masyarakat yang semakin baik, merupakan indikasi dari empowering yang dialami oleh masyarakat (Thoha, 2002: 24).

\section{Pengertian Akta Kelahiran}

Akta kelahiran merupakan dokumen resmi yang dikeluarkan oleh pemerintah melalui dinas terkait yang berfungsi sebagai:

a. Akta kelahiran merupakan bukti sah paling kuat dalam menentukan kedudukan hukum seseorang

b. Merupakan akta otentik yang mempunyai kekuatan hukum pembuktian sempurna di depan hakim.

c. Memberikan kepastian hukum sebesar-besarnya tentang kejadian-kejadian mengenai kelahiran, perkawinan, perceraian, pengakuan/pengesahan anak dan kematian.

d. Dari segi praktisnya akta-akta kelahiran dari catatan sipil dapat dipergunakan untuk tanda bukti otentik dalam hal pengurusan pasport kewarganegaraan, KTP,

e. Keperluan sekolah, masuk TNI dan utama menentukan status ahli waris dan sebagainya.

Standar Operasional Prosedur (SOP) adalah suatu kegiatan rutin yang memungkinkan para pegawai (atau pelaksana kebijakan/administrator/birokrat) untuk melaksanakan kegiatan-kegiatannya setiap hari sesuai dengan standar yang ditetapkan atau standar minimum yang dibutuhkan. Dengan menerapkan SOP tersebut, diharapkan pelayanan yang diberikan semakin baik. Berdasarkan hal tersebut, secara skematis kerangka pemikiran dalam penelitian ini adalah sebagai berikut

\section{KERANGKA ANALISIS}

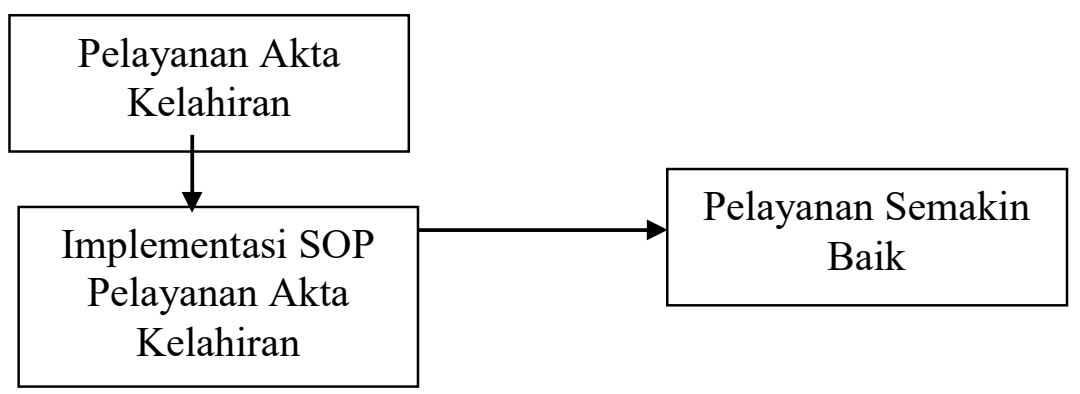

Gambar 2. Kerangka Pemikiran

\section{METODOLOGI}

Metode penelitian adalah keseluruhan proses berpikir dari mulai menemukan masalah penelitian sampai menjabarkannya ke dalam suatu kerangka teoritis tertentu, serta pengumpulan data bagi pengujian empiris sampai dengan penjelasan dan penarikan kesimpulan gejala sosial yang diteliti (Sugiyono, 2010:343). Metode yang digunakan dalam penelitian ini adalah metode deskriptif kualitatif yang dilakukan melalui survei, wawancara, dan dokumentasi yang dilakukan untuk mendapatkan temuan atau data yang lebih bermakna dengan latar belakang dan dihasilkan data yang bersipat deskriptif.

Alasan utama menggunakan metode deskriptif kualitatif adalah bahwa ada proses dan interaksi yang terjadi dalam pelaksanaan kegiatan pelayanan. Jadi, analisis deskriptif merupakan metode mempelajari proses berinteraksi dengan satu orang atau organisasi.Tujuannya adalah mengetahui lebih banyak tentang bagaimana proses-proses tersebut berlangsung pada tipe organisasi atau orang yang bertipe sama (Yin, 1994:312). 
Analisis data dalam penelitian adalah analisis kualitatif. Analisis kualitatif menggunakan analisis data induktif, dengan cara ini konteksnya akan lebih mudah dideskripsikan (Muhadjir, 2002:33). Data yang dikumpulkan dalam penelitian ini adalah data yang berkaitan dengan budaya organisasi dan kinerja pegawai.

Proses analisis dalam penelitian kualitatif ini dilakukan bersifat siklus yang dilakukan sewaktu peneliti berada dilapangan maupun setelah peneliti meninggalkan lapangan penelitian. Untukmenyajikan data agar lebih bermakna dan mudah dipahami, ada tiga alur kegiatan proses analisis data yang dilakukan peneliti secara bersamaan yaitu: reduksi data, penyajian data, penyajian data dan penarikan kesimpulan atau verifikasi (Miles dan Huberman, 1992:16:121).

\section{HASIL DAN PEMBAHASAN}

\section{Tahap Persiapan dalam Implementasi SOP Akta Kelahiran}

SOP adalah petunjuk baku yang berisi serangkaian instruksi tertulis mengenai berbagai proses penyelenggaraan administrasi perusahaan dan atau organisasi. Di dalam SOP ada kejelasan mengenai bagaimana dan kapan dilakukan, di mana dan oleh siapa dilakukan dan dalam konteks pekerjaan atau pelayanan apa. SOP pelayanan penerbitan akta kelahiran adalah serangkaian instruksi tertulis mengenai proses penyelenggaraan pelayanan penerbitan akta kelahiran dan menjadi acuan baku yang harus dilaksanakan secara baik dan sistematis.

Dalam tahap implementasi SOP, kegiatan persiapan implementasi merupakan kegiatan yang sangat penting dilakukan. Selain untuk mengkomunikasikan SOP pelayanan akta kelahiran kepada pegawai pelayanan juga sebagai informasi kepada masyarakat bahwa setiap ada masyarakat yang melakukan pengurusan pelayanan akta kelahiran, masyarakat telah mengetahui persyaratan dan prosedur yang akan dilalui.

Di lingkungan intern Dinas Dukcapil Kota Bengkulu, sosialisasi SOP sekaligus perumusan SOP telah dilakukan sebagai salah satu langkah awal dalam tahap persiapan implementasi SOP pelayanan akta kelahiran. Kegiatan sosilasasi tersebut dilakukan pada 02 Februari 2014, sementara sosialisasi SOP di tingkat SKPD dilakukan pada 24-25 November 2014 bertempat di Aula Penginapan Dinda Ceria. Hadir dalam acara tersebut adalah perawakilan SKPD dan perwakilan masyarakat.

Setelah sosialisasi SOP secara intern dilakukan, langkah-langkah yang diambil oleh pimpinan Dinas Kependudukan dan Pencatatan Sipil Kota Bengkulu adalah:

a) Melakukan persiapan teknis pelaksanaan SOP pelayanan. Kegiatan ini meliputi penyiapan dan penataan ruangan pelayanan, peralatan pokok dan perlengkapan penunjang lainnya.

b) Melakukan persiapan administrasi pelayanan seperti menyiapan buku induk pelayanan, ATK dan sebagainya terkait dengan pelaksanaan pelayanan.

c) Melakukan persiapan staf dan pembagian tugas. Langkah ini dilakukan agar pelaksanaan pelayanan berjalan baik, efektif dan efisien karena. Petugas pelayanan yang ditetapkan sebanyak 6 orang yang terdiri dari 2 orang operator, 2 orang petugas administrasi dan 2 orang petugas register.

Dari hasil penelitian diketahui bahwa tahap persiapan telah dilakukan secara matang dan baik, hal ini terlihat dari kelengkapan peralatan dan perlengkapan penunjang dan kesiapan petugas yang siap memberikan pelayanan akta pencatatan sipil (termasuk pelayanan akta kelahiran) kepada masyarakat yang datang.

\section{Tahap Pelaksanaan SOP Akta Kelahiran}

Hasil penelitian menunjukkan bahwa pelaksanaan penerbitan akta kelahiran di Dinas Kependudukan dan Pencatatan Sipil Kota Bengkulu sudah sesuai dengan Standar Operasional Prosedur (SOP) yang telah ditetapkan. Hal ini dapat dilihat dari tahap-tahap pelaksanaan yaitu mulai dari persiapan mulai dari sosialisasi dan penyatuan visi/misi kepada pegawai, persiapan teknisnya baik dari segi peralatan dan perlengkapan pelayanan, persiapan administrasi dan persiapan staf dan pembagian tugas yang dilakukan oleh kepala bidang dan kepala dinas dalam kegiatan rutin rapat staf.

Dalam pelaksanaan pelayanan penerbitan akta kelahiran, ada beberapa dokumen yang harus diganti terlebih dahulu yaitu: penambahan nama anggota baru di dalam Kartu Keluarga (KK) sehingga anggota baru bisa mendapatkan NIK (Nomor Induk Kependudukan), dokumen seperti nama orang tua di KK harus sama dengan buku nikah dan lain-lain. Hal seperti ini lah yang membuat masyarakat bolak-balik untuk mengurus berkas-berkas yang belum lengkap, sehingga menganggap bahwa pihak Dinas Kependudukan dan Pencatatan Sipil mempersulit masyarakat dan menganggap bahwa urusan dalam 
membuat akta kelahiran berbelit-belit dan semacamnya. Padahal hal tersebut merupakan persyaratan yang harus dipenuhi oleh masyarakat pemohon agar dapat memperoleh akta kelahiran.

Untuk mengetahui pelaksanaan pelayanan yang telah dilakukan, setiap tiga bulan sekali dilakukan evaluasi dari pelayanan penerbitan dokumen kependudukan yang dilaksanakan di Dinas Kependudukan dan Pencatatan Sipil Kota Bengkulu. Sebagaimana disampaikan informasi bahwa rapat staf dilakukan tiga bulan sekali untuk mengetahui kendala-kendala yang dihadapi dan mencari solusi dalam memberikan pelayanan dokumen administrasi kependudukan kepada masyarakat. Begitu pula pada tahap implementasi SOP yang telah berjalan sesuai dengan aturan yang telah ditetapkan mulai dari penerimaan berkas permohonan penerbitan akta kelahiran, verifikasi berkas, pengagendaan dan pengumpulan berkas kemudian input data dan cetak blanko kutipan akta kelahiran, tahap pemeriksaan, pemarafan dan penandatanganan kutipan akta kelahiran telah sesuai dengan waktu yang ditetapkan.

Sebagaimana informasi dari petugas pelayanan bahwa apabila tidak terkendala teknis maka semua berkas permohonan yang masuk dan telah lengkap dapat diproses sesuai dengan yang ditentukan kurang lebih dua hari sesuai dengan aturan yang berlaku.

Berkaitan dengan hasil penelitian dan teori implementasi kebijakan publik, keberhasilan dari implementasi tersebut tergantung pada pelaksanaan proses implementasi tersebut. Dalam teori implementasi, tahap penerapan kebijakan merupakan tahap yang krusial dalam proses kebijakan publik. Implementasi merupakan tahapan atau serangkaian kegiatan setelah suatu kebijakan dirumuskan. Tanpa suatu implementasi maka suatu kebijakan yang telah dirumuskan akan sia-sia belaka. Implementasi kebijakan merupakan hal yang paling berat, karena disini masalah-masalah yang kadang tidak dijumpai dalam konsep, muncul di lapangan (Nugroho, 2006:119).

Repley dan Franklin (dalam Alfatih, 2010:51), menulis tentang tiga konsep hubungan untuk kesuksesan sebuah implementasi kebijakan sebagaimana pernyataannya sebagai berikut:

Gagasan tentang keberhasilan dalam pelaksanaan telah diterima secara luas. Beberapa ahli dan peneliti memiliki pengertian yang sangat berbeda mengenai kunci sukses implementasi. Menurutnya, ada tiga cara yang dominan berpikir tentang sukses implementasi, yakni kepatuhan, kelancaran, dan dampak yang diinginkan.

Sehubungan dengan tiga konsep hubungan untuk kesuksesan sebuah implementasi kebijakan tersebut, dinyatakan bahwa ada ahli dan pengambil kebijakan yang berpendapat bahwa implementasi kebijakan yang berhasil dinilai, pertama, memakai ukuran tingkat kepatuhan (degree of compliance). Kedua, ada juga yang mengukur adanya kelancaran rutinitas fungsi. Oleh karena Ripley dan Franklin menganggap kedua parameter tersebut adalah pembatasan politis, maka mereka mengajukan perspektif yang ketiga, yaitu dampak yang diinginkan. Mereka mengutarakan ini dengan mengatakan "kami membantu ketiga perspektif implementasi, yang mana kunci sukses itu adalah kemampuan memimpin ke arah tujuan yang dikehendaki".Jadi ada tiga perspektif untuk mengukur keberhasilan impelementasi kebijakan. Ketiga measurement tersebut adalah:

1) Tingkat kepatuhan pada ketentuan yang berlaku. Perspektif pertama (compliance perspective) memahami keberhasilan implementasi dalam arti sempit yaitu sebagai kepatuhan para implementor dalam melaksanakan kebijakan yang tertuang dalam dokumen kebijakan (dalam bentuk undang-undang, peraturan pemerintah, SOP dan/atau program.

2) Lancarnya pelaksanaan rutinitas fungsi. Keberhasilan implementasi ditandai dengan lancarnya rutinitas fungsi dan tidak adanya masalah- masalah yang dihadapi.

3) Terwujudnya kinerja dan dampak yang dikehendaki. Keberhasilan suatu implementasi mengacu dan mengarah pada implementasi/pelaksanaan dan dampaknya (manfaat) yang dikehendaki dari semua program-program yang dikehendaki.

Pendapat Ripley dan Franklin diatas menunjukkan bahwa keberhasilan suatu implementasi akan ditentukan bagaimana tingkat kepatuhan, lancarnya rutinitas fungsi lembaga, dan hasil kebijakan yang sesuai dengan rencana dari kebijakan. Dalam penelitian ini, ketiga perspektif itu dipakai sebagai pedoman untuk mengukur keberhasilan implementasi penerapan Standar Operasional Prosedur (SOP). Hal ini dikarenakan ketiga persepektif tersebut tidak kontradiksi satu dengan yang lain, bahkan mereka saling melengkapi sehingga ketiga persepektif tersebut lebih holistic, oleh karenanya cocok dengan penelitian ini.

Pelayanan publik merupakan produk birokrasi publik yang diterima oleh warga pengguna maupun masyarakat secara luas. Karena itu, pelayanan publik dapat didefinisikan sebagai serangkaian aktivitas yang dilakukan oleh birokrasi publik untuk memenuhi kebutuhan warga pengguna. Pengguna 
yang dimaksud ialah warga Negara atau masyarakat yang membutuhkan pelayanan publik, seperti Pembuatan akta Kelahiran, Akta Kematian, Akta Nikah, Pembuatan Kartu Tanda Penduduk, dan lain-lain.

Sejalan dengan kebutuhan masyarakat akan pelayanan yang berkualitas dari pemerintah, maka sebagai pelayanan publik yang mendapat kepercayaan dari masyarakat, mereka harus senantiasa mengacu pada kepuasan total para pelanggan yang merupakan tujuan pokok dalam pemberian pelayanan. Karena itu perbaikan kualitas hendaknya secara terus menerus/berkesinambungan.

Keberadaan Standar Operasional Prosedur sebagai bagian penting dari pelaksanaan tugas dan fungsi pelayanan kepada masyarakat dan juga sebagai sebuah sistem pengawasan manajemen (management control system). SOP merupakan sebagai peraturan dan regulasi yang merupakan kebijakan untuk menjamin kebenaran (validitas) perilaku anggota organisasi secara terus menerus.

Sebagai suatu instrumen manajemen, SOP yang berlandaskan pada sistem manajemen kualitas (Quality Management System), yakni sekumpulan prosedur terdokumentasi dan praktek-praktek standar untuk manajemen sistem yang bertujuan menjamin kesesuaian dari suatu proses dan produk (barang dan/atau jasa) terhadap kebutuhan atau persyaratan tertentu. Sistem manajemen kualitas berfokus pada konsistensi dari proses kerja. Hal ini mencakup beberapa tingkat dokumentasi terhadap standar-standar kerja. Sistem ini berlandaskan pada pencegahan kesalahan, sehingga bersifat proaktif, bukan pada deteksi kesalahan yang bersifat reaktif.

Terkait dengan pelaksanaan SOP penerbitan pelayanan akta kelahiran dalam peningkatan pelayanan dan kinerja organisasi dalam administrasi perkantoran maka SOP berperan sebagai pengembangan misi organisasi secara umum dan misi administrasi perkantoran secara khusus. Hal ini berarti dengan adanya SOP maka pengembangan misi organisasi ataupun misi administrasi perkantoran menjadi lebih mudah karena dengan adanya SOP maka akan tergambarkan kaitan aktivitas satu dengan aktivitas yang lain sehingga pengembanan aktivitas yang satu akan berimplikasi pada pengembangan aktivitas yang kesemuanya tersiratkan dalam SOP yang telah ada maupun SOP yang potensial harus ada.

SOP sebagai sebuah dokumen mengenai prosedur pelaksanaan pekerjaan administrasi perkantoran memberikan manfaat sebagai metode terbaik bagian/unit pelaksana administrasi perkantoran dalam mengoperasionalisasikan (melaksanakan) dokumen organisasi dengan peraturan, rencana, kebijakan, strategi operasional, kerjasama, dan sebagainya; mempercepat dokumentasi konsepkonsep penting, teknik, dan persyaratan ke dalam format yang dapat segera digunakan oleh pegawai/pekerja di bagian/unit administrasi perkantoran dalam pekerjaan sehari-hari mereka; SOP membantu untuk menyatukan operasi bagian/unit adminisrasi perkantoran dengan pekerjaan para manajer dan perencana dengan aktivitas pekerja lainnya.

\section{KESIMPULAN}

1. Pada tahap persiapan pelaksanaan SOP pelayanan penerbitan akta kelahiran di Dinas Dukcapil Kota Bengkulu telah dilaksanakan dengan baik. Sosialisasi SOP telah dilakukan dengan baik, sarana dan prasarana pelayanan telah disusun dengan baik, tugas dan tanggung jawab petugas telah dibagi dengan tepat, sehingga memperlancar proses pelayanan kepada masyarakat. Sosialisasi dilakukan melalui rapat staf tiap tiga bulan sekali yang bertujuan untuk mengevaluasi kinerja layanan akta catatan sipil termasuk didalamnya pelayanan akta kelahiran. Dari kegiatan rapat evaluasi tersebut diidentifikasi faktor penghambat layanan dan dibahas bersama untuk mencari solusinya. Sosialisasi SOP kepada masyarakat dilakukan dengan cara menempel Alur Pelayanan (SOP) pada papan pengumunan di Kantor Dinas Kependudukan dan Pencatatan Sipil, agar masyarakat yang datang dapat melihat langsung alur pelayanan yang diselenggarakan oleh Dinas Dukcapil Kota Bengkulu.

2. Implementasi SOP dalam pelaksanaan penerbitan akta kelahiran di Dinas Dukcapil Kota Bengkulu dari tahap menerima dan memeriksa berkas permohonan akta kelahiran, verifikasi berkas permohonan, mengagendakan dan mengumpulkan berkas permohonan, menginput data dan mencetak akta kelahiran, memeriksa, memaraf dan menandatangani, dan menyerahkan kutipan akta kelahiran kepada masyarakat telah dilaksanakan sesuai dengan tahapan pelayanan yang ditetapkan. Waktu yang dibutuhkan dalam penerbitan akta kelahiran adalah 2 hari kerja. Setiap pegawai yang terlibat dalam pelayanan akta kelahiran telah bekerja sesuai dengan tanggung jawabnya masing-masing.

\section{SARAN}


1. Mempertahankan pelayanan yang sudah baik selama ini dan tetap mengadakan evaluasi serta survey kepuasan pelanggan agar dapat diketahui kekurangan dan kelemahan dalam pelaksanaan pelayanan akta kelahiran di kemudian hari sehingga dapat diperbaiki.

2. Bagi petugas pelayanan agar dapat melaksanakan seluruh pelayanan publik sesuai dengan tugas pokok dan kewenangan dalam memberikan pelayanan kepada masyarakat.

3. Perlu adanya kotak saran untuk menampung aspirasi atau keluhan masyarakat yang selama ini belum ada, sehingga kinerja pelayanan dapat diperbaiki di masa mendatang.

4. Pemberian informasi yang jelas kepada masyarakat mengenai prosedur pelayanan publik di Dinas Dukcapil Kota Bengkulu, baik secara tertulis dan lisan dalam konteks yang lebih luas seperti sosialisasi di tingkat desa/ kelurahan, sehingga masyarakat mengerti dengan baik.

\section{DAFTAR PUSTAKA}

Alfatih, M., 2010. Administrasi Kebijakan Publik, LAN-RI, Jakarta

Dye, Thomas R, 1995. Implementing Public Policy. Washington: Congressional Quarterly Press

Fatah, Agam, 2000, Manajemen Keuangan Publik, Materi Pelatihan Anti Korupsi, Indonesian Coruption Watch, 23-25 Januari 2002, Jakarta.

Gie, Kwik Kian, 2000. Manajemen Administrasi Publik, LP3ES, Jakarta

Hardiansyah, 2011. Kualitas Pelayanan Publik, Yogyakarta: Gava Media

Ibrahim, Amin, 2008. Teori dan Konsep Pelayanan Publik Implementasinya. Mandar Maju. Bandung.

Marijan, 2010. Buku Pintar Manajemen Kinerja. Terjemahan Anthony R Indra. Metalexia Publishing \& Pt Qreator Tata Qarakter. Jakarta.

Muhadjir, 2002. Metode Penelitian Kualitatif, Alfabeta, Bandung

Nugroho, 2006. Analisis Kebijakan Publik: Panduan Praktis Mengkaji Masalah dan Kebijakan Sosial. Bandung: Alfabeta.

Parson, Wayne, 2008. Public Policy: An Introduction to The Theory and Practice, (Tri Wibowo Budi Santoso, Penerjemah). Jakarta:

Peraturan Metreri Negara dan Reformasi Birokrasi RI Nomor 35 Tahun 2012 Tentang Pedoman Penyusunan Standar Operating Prosedure (SOP) Administrasi Pemerintahan

Purwanto, N., 2012. Kebijaksanaan Negara: Konsistensi dan Implementasi, LP3ES, Jakarta

Shadely, Hasan, 1996. Kamus Besar Bahasa Indonesia, PT Indeks. Jakarta

Sugiyono. 2010. Metode Penelitian, Bandung: Alfabeta.

Thoha, M., 2002. Manajemen Pelayanan Umum, LP3ES, Jakarta

Yin, Robert K. 1994. Sudi Kasus: Risert Desain dan Metode (M Djauzi Mudzakir, Penerjemah). Jakarta: Raja Grafindo 